\title{
Molecular prevalence of trichomonad species from pet shop puppies and kittens in Japan
}

\author{
Molecular prevalência de espécies trichomonas em filhotes de cães e gatos de \\ pet shop no Japão
}

\author{
Naoyuki Itoh* (1); Yuko lijima; Isao Ogura²; Natsumi Yonekura²; Satoshi Kameshima'; Yuya Kimura \\ ${ }^{1}$ Laboratory of Small Animal Internal Medicine, School of Veterinary Medicine, Kitasato University, Towada, Aomori, Japan \\ ${ }^{2}$ Kojima Animal Hospital, Koto-Ku, Tokyo, Japan
}

How to cite: Itoh N, lijima Y, Ogura I, Yonekura N, Kameshima S, Kimura Y. Molecular prevalence of trichomonad species from pet shop puppies and kittens in Japan. Braz J Vet Parasito/ 2020; 29(4): e014820. https://doi.org/10.1590/S1984-29612020098

\begin{abstract}
Pentatrichomonas hominis and Tritrichomonas foetus (cat genotype) have been commonly identified as intestinal trichomonads in both dogs and cats. Although P. hominis is considered as non-pathogenic protozoa in many kinds of mammals, it has the potential for zoonotic transmission. T. foetus has been recognized as the emerging causative agent of diarrhea in cats without the risk of zoonotic transmission. As pet shops are the major source of young companion animals, the present study discusses the molecular prevalence of $P$. hominis and $T$. foetus from 544 pet shop puppies and 409 kittens. The results suggest that the prevalence of $P$. hominis (puppies: $7.0 \%$; kittens: $0.5 \%$ ) and $T$. foetus (puppies: $0 \%$; kittens: $2.4 \%$ ) in pet shop young animals are low. In addition, the infections of $P$. hominis and $T$. foetus are not always associated with the clinical signs (soft or diarrhea feces).
\end{abstract}

Keywords: Pentatrichomonas hominis, Tritrichomonas foetus, puppy, kitten, pet shop.

\section{Resumo}

Pentatrichomonas hominis e Tritrichomonas foetus (genótipo de gato) têm sido comumente identificados como trichomonas intestinais em cães e gatos. Apesar de $P$. hominis ser considerado como protozoário não patogênico em muitos tipos de mamíferos, tem potencial para transmissão zoonótica. Enquanto o T. fetus foi reconhecido como o agente causador emergente de diarreia em gatos sem o risco de transmissão zoonótica. Devido às lojas de animais serem as principais fontes de filhotes de animais domésticos, o presente estudo discute a prevalência molecular e/ou o potencial zoonótico de $P$. hominis e $T$. foetus em 544 filhotes de cachorro e 409 gatos de "pet shop". Os resultados sugerem que a prevalência de $P$. hominis (cães: 7,0\%; gatos: 0,5\%) e T. foetus (cães: 0\%; gatos: $2,4 \%)$ em animais jovens de "pet shop" é baixa. Além disso, as infecções de $P$. hominis e $T$. foetus nem sempre estão associadas aos sinais clínicos (fezes moles ou diarreia).

Palavras-chave: Pentatrichomonas hominis, Tritrichomonas foetus, filhote de cachorro, filhote de gato, pet shop. 


\section{Introduction}

In both dogs and cats, two species of intestinal trichomonads, Pentatrichomonas hominis and Tritrichomonas foetus (cat genotype), have been identified (Gookin et al., 2007; Li et al., 2016a). It remains still controversial whether these parasites are pathogenic or not. In general, $P$. hominis is considered as non-pathogenic opportunistic protozoa in many kinds of mammals including dog, cats, and humans (Maritz et al., 2014). However, some previous reports suggest an association of $P$. hominis infection with the occurrence of diarrhea (Bastos et al., 2018; Kim et al., 2010; Meloni et al., 2011; Zhang et al., 2019). In addition, the dogs and cats infected with $P$. hominis have the potential as reservoir for zoonotic transmission. $T$. foetus has been recognized as the emerging causative agent of chronic diarrhea in cats (Bastos et al., 2019; Hora et al., 2017; Yao \& Köster, 2015). Hence, intestinal trichomonads in dogs and cats are obviously significant as potential pathogen and/or as zoonotic agent. As pet shops are the major source of young companion animals for owners, the present study discusses the molecular prevalence of $P$. hominis and T. foetus from pet shop puppies and kittens in Japan.

\section{Materials and Methods}

Between October 2017 and September 2018, a total of 544 and 409 fecal samples were collected randomly from pet shop puppies and kittens in Japan, respectively. All of the animals were aged 1-3 months. After natural defecation, the fresh feces were visually evaluated by veterinarians as follows: Normal (hard or moderate soft formed stool), Soft (evidently moist formed stool), and Diarrhea (watery liquid stool). The stool specimens were immediately submitted to the laboratory on ice from three pet shops located in two different prefectures (Shop A-C) for puppies and from two pet shops (Shop A, B) for kittens, and were stored at $4{ }^{\circ} \mathrm{C}$ prior to DNA extraction (within three days). The outlines of pet shops were as follows: Shop A (223 puppies; 234 kittens, Koto-ku in Tokyo), Shop B (282 puppies; 175 kittens, Hirosaki-city in Aomori), and Shop C (39 puppies, Hachinohe-city in Aomori). The trichomonad genomic DNA extraction from fecal samples was performed using QIAamp Fast DNA Stool Mini Kit (QIAGEN GmbH, Hilden, Germany) according to the manufacturer's instructions. The extracted DNA samples were stored at $-20^{\circ} \mathrm{C}$ until polymerase chain reaction (PCR) analysis.

According to the previous study (Kamaruddin et al., 2014), a nested PCR targeting the partial small subunit ribosomal RNA gene was employed for the detection of trichomonad species. The sequences of each primer and the cycling conditions are shown in Table 1. In the primary reaction, the PCR mixture comprised $1 \times$ buffer containing $3.0 \mathrm{mM}$ of $\mathrm{MgCl}_{2}, 200 \mu \mathrm{M}$ of each dNTP, $0.5 \mu \mathrm{M}$ of each primer, 1.25 units of GoTaq DNA polymerase (Promega Corporation, Madison, WI, USA), and 3.0 $\mu$ l of template DNA (1-5 ng DNA) in a total reaction volume of $25 \mu \mathrm{l}$. In the secondary reaction, the PCR mixture was the same as that for the primary reaction, with the exception of the primary PCR amplicons, which were used as a template $(3.0 \mu \mathrm{l})$.

Table 1. Polymerase chain reaction primers, annealing temperatures, and expected sizes of amplicons.

\begin{tabular}{|c|c|c|c|c|c|}
\hline PCR & $\begin{array}{l}\text { Primers } \\
\text { names }\end{array}$ & Primers sequence ( $5^{\prime}$ to $\left.3^{\prime}\right)$ & $\begin{array}{c}\text { Annealing } \\
\text { temperature } \\
\left({ }^{\circ} \mathrm{C}\right)\end{array}$ & $\begin{array}{l}\text { Amplicon } \\
\text { size (bp) }\end{array}$ & Reference \\
\hline \multirow[t]{2}{*}{ Primary } & MK1 & GTAGGCTATCACGGGTAACG & 66 & 10,80 & Kamaruddin et al. (2014) \\
\hline & MK6 & GTTGACACACATTTACAAGGGATTCC & & & \\
\hline \multirow[t]{2}{*}{ Secondary } & MK5 & GCAGCAGGCGCGAAACTTAC & 64 & 850 & \\
\hline & MK4 & GGACATCACGGACCTGTTATTGCTAC & & & \\
\hline
\end{tabular}

The cycling conditions of PCRs were as follows. In primary reaction, after an initial denaturation of 3 min at $94{ }^{\circ} \mathrm{C}, 35$ cycles were preformed, each consisting of $30 \mathrm{sec} 94^{\circ} \mathrm{C}$ for denaturation, $30 \mathrm{sec}$ at $66^{\circ} \mathrm{C}$ for annealing, and $60 \mathrm{sec}$ at $72{ }^{\circ} \mathrm{C}$ for extension, with a final extension of 5 min at $72{ }^{\circ} \mathrm{C}$. In secondary reaction, the cycling conditions were the same as primary reaction, except that the annealing temperature was $64^{\circ} \mathrm{C}$.

All secondary PCR amplicons were identified via electrophoresis on 1.5\% agarose gels. The specific DNA fragments were confirmed after staining with AtlasSight DNA Stain (Bioatlas, Tartu, Estonia) under UV light using a transilluminator. After the amplicons of predicted size were purified using a QIAquick Gel Extraction Kit (QIAGEN), those were sequenced in a commercial laboratory (FASMAC Co., Ltd., Atsugi, Kanagawa, Japan). Sequence alignment and compilation were carried out using the MEGA 7.0.26 program (MEGA, 2020). To determine the species of trichomonad, the obtained DNA sequences were compared to GenBank references by BLAST searches (NCBI, 2020). 
The data were stratified according to pet shop and fecal condition (normal vs. soft vs. diarrhea) and were analyzed statistically with pairwise comparisons using Fisher's exact probability test. The $P$ values were adjusted for multiple test procedure by Holm's method and significant level was set to $P<0.05$. Statistical analysis was performed using the software of R version 4.0.2 (The R Foundation for Statistical Computing, Vienna).

\section{Results}

The results of the present study are summarized in Table 2. Overall prevalence of trichomonad species in pet shop puppies and kittens were 7.0\% (38/544) and 2.9\% (12/409), respectively. According to the sequencing analysis, all of 38 isolates from puppies were corresponding to $P$. hominis with the similarity of 99.0-100\% (accession number KC594038). From kittens, 10 isolates $(2.4 \% ; 10 / 409)$ were corresponding to $T$. foetus with the similarity of 99.8-100\% (accession number AF466749), and the remainder two isolates $(0.5 \% ; 2 / 409)$ were $P$. hominis with the similarity of $99.4 \%$ (accession number KC594038).

Table 2. Molecular prevalence of trichomonad species from pet shop puppies and kittens in Japan.

\begin{tabular}{|c|c|c|c|c|c|c|c|}
\hline & \multirow[b]{2}{*}{ Examined no. } & \multicolumn{2}{|c|}{ Pentatrichomonas hominis } & \multicolumn{2}{|c|}{ Tritrichomonas foetus } & \multicolumn{2}{|c|}{ Total } \\
\hline & & $\begin{array}{c}\text { Positive } \\
\text { no. }\end{array}$ & Prevalence & $\begin{array}{c}\text { Positive } \\
\text { no. }\end{array}$ & Prevalence & $\begin{array}{c}\text { Positive } \\
\text { no. }\end{array}$ & Prevalence \\
\hline \multicolumn{8}{|l|}{ Puppies } \\
\hline Overall & 544 & 38 & $7.0 \%$ & 0 & $0 \%$ & 38 & $7.0 \%$ \\
\hline \multicolumn{8}{|l|}{ Pet shops } \\
\hline Shop A & 223 & 7 & $3.1 \%$ & 0 & $0 \%$ & 7 & $3.1 \%$ * \\
\hline Shop B & 282 & 28 & $9.9 \%$ & 0 & $0 \%$ & 28 & $9.9 \%{ }^{\#}$ \\
\hline Shop C & 39 & 3 & $7.7 \%$ & 0 & $0 \%$ & 3 & $7.7 \%$ \\
\hline \multicolumn{8}{|l|}{$\begin{array}{c}\text { Fecal } \\
\text { condition }\end{array}$} \\
\hline Normal & 519 & 36 & $6.9 \%$ & 0 & $0 \%$ & 36 & $6.9 \%$ \\
\hline Soft & 13 & 1 & $7.7 \%$ & 0 & $0 \%$ & 1 & $7.7 \%$ \\
\hline Diarrhea & 12 & 1 & $8.3 \%$ & 0 & $0 \%$ & 1 & $8.3 \%$ \\
\hline \multicolumn{8}{|l|}{ Kittens } \\
\hline Overall & 409 & 2 & $0.5 \%$ & 10 & $2.4 \%$ & 12 & $2.9 \%$ \\
\hline \multicolumn{8}{|l|}{ Pet shops } \\
\hline Shop A & 234 & 0 & $0 \%$ & 7 & $3.0 \%$ & 7 & $3.0 \%$ \\
\hline Shop B & 175 & 2 & $1.1 \%$ & 3 & $1.7 \%$ & 5 & $2.9 \%$ \\
\hline \multicolumn{8}{|l|}{$\begin{array}{c}\text { Fecal } \\
\text { condition }\end{array}$} \\
\hline Normal & 384 & 2 & $0.5 \%$ & 10 & $2.6 \%$ & 12 & $3.1 \%$ \\
\hline Soft & 18 & 0 & $0 \%$ & 0 & $0 \%$ & 0 & $0 \%$ \\
\hline Diarrhea & 7 & 0 & $0 \%$ & 0 & $0 \%$ & 0 & $0 \%$ \\
\hline
\end{tabular}

${ }^{*}$ Vs $\#$; $\mathrm{P}<0.01$.

The prevalence of $P$. hominis in each pet shop puppies were as follows: 3.1\% (7/223) in Shop A, 9.9\% (28/282) in Shop B, and 7.7\% (3/39) in Shop C. The ratio in Shop B was significantly $(P<0.01)$ higher than that in Shop A.

The frequencies of trichomonads in two pet shop kittens were 3.0\% (7/234) in Shop A and 2.9\% (5/175) in Shop B, with no significant difference. The trichomonad species from kittens in Shop A demonstrated that all seven isolates were $T$. foetus. While in Shop B, the identified species were three isolates of $T$. foetus and two isolates of $P$. hominis. 
According to the fecal condition, in puppies, the prevalence was 6.9\% (36/519) in normal, $7.7 \%(1 / 13)$ in soft, and $8.3 \%(1 / 12)$ in diarrhea. Hence, there was no significant differences among fecal conditions. In kittens, the frequency of normal vs. soft vs. diarrhea was $3.1 \%(12 / 384)$ vs. $0 \%(0 / 18)$ vs. $0 \%(0 / 7)$, without significant differences.

\section{Discussion}

The present study is the first report that evaluated the prevalence of intestinal trichomonad species from pet shop puppies and kittens in Japan. In puppies, only $P$. hominis infection was determined. In contrast, $T$. foetus infection was identified in kittens, with a few cases of $P$. hominis infections, but the case of coinfection with two organisms was none. Corresponding with the present results, the previous reports demonstrated that $P$. hominis and T. foetus infections were dominant for dogs and cats, respectively (Bastos et al., 2019; Grellet et al., 2013; Li et al., 2016a, 2019; Maritz et al., 2014). In addition, P. hominis was sometimes isolated from cats, but $T$. foetus infection was determined in cats, and it was markedly rare in dogs (Bastos et al., 2018; Gookin et al., 2007; Li et al., 2016a, 2019;). To our knowledge, in the last decade, there were no available investigations for trichomonad infections, targeting the pet shop puppies and kittens. However, there are several reports that represent the status in pet shop animals. The recent molecular prevalence of $P$. hominis from young dogs has been recorded as follows: $17.4 \%$ (19/109; breeding kennel dogs aged <8 weeks) in France (Grellet et al., 2013), 41.5\% (49/118; police dogs and rural district dogs aged $\leq 6$ months) in China (Li et al., 2016b), 12.5\% (4/32; breeding kennel dogs aged $\leq 6$ months) in Poland (Michalczyk et al., 2015) and 53.3\% (24/45; household dogs aged $\leq 12$ months) in China (Li et al., 2016a). In young cats, the following molecular prevalence of $T$. foetus was lately described: $26.3 \%$ (5/19; show cats aged $<12$ months) in Norway (Tysnes et al., 2011), 11.7\% (7/60; household cats aged $\leq 12$ months) in China (Li et al., 2019) and 33.3\% (12/36; household cats aged $\leq 12$ months) in Poland (Dąbrowska et al., 2020). Authors started the present investigation with a hypothesis that pet shop puppies and kittens showed a high-level prevalence for intestinal trichomonads. Because the higher prevalence of $P$. hominis and $T$. foetus was suggested in young dogs and cats, based on the high-density animals in limited space, suspected stressful situation, and their immature immune system (Bastos et al., 2019; Dąbrowska et al., 2020; Grellet et al., 2013; Li et al., 2016a, b; Tysnes et al., 2011; Yao \& Köster, 2015). Additionally, the behavior of puppy, particularly the habit of biting and licking objects which has the potential of contamination with trichomonads is also likely a significant contribution factor for transmission. Similarly, the behavior of grooming, characteristic in cats, seems to associate with transmission through the physical contamination. The present study was carried out in puppies and kittens aged $\leq 3$ months. Nevertheless, the overall prevalence was unexpectedly low. It is difficult to determine the exact reasons for the above contradicting results. However, several factors are suspected. Considering the investigated populations, a part of the results in previous studies were obtained from smaller size of examined numbers, which included subconsciously a higher risk for misunderstanding. The fecal condition is also probably one of the factors that influenced the results. The higher prevalence of trichomonad infections was recorded from the fecal samples of soft/diarrhea in dogs and cats (Dąbrowska et al., 2020; Li et al., 2016a). Although we could not obtain the detailed data from referring studies here, the fecal conditions of soft/diarrhea were of high percentage such as 13.8-41.1\% in overall (Dąbrowska et al., 2020; Li et al., 2016a, 2019; Tysnes et al., 2011). In contrast, the percentages of the feces with soft and diarrhea in the present study were low such as 2.4\% (13/544) and 2.2\% (12/544) in puppies, and 4.4\% (18/409) and 1.7\% (7/409) in kittens, respectively. Another suspected factor is surely the environmental contamination. The infectious route of $P$. hominis and T. foetus is limited only via fecal-oral transmission (Bastos et al., 2019; Maritz et al., 2014; Yao \& Köster, 2015). The intestinal trichomonads are shed into the environment at trophozoite stage and the several days' survival of $P$. hominis and $T$. foetus in feces, which means environmental contamination, has been suggested (Grellet et al., 2013; Meloni et al., 2011; Yao \& Köster, 2015). Thus, it is supposed that the lower prevalence in the present study is due to satisfactory sanitary control in all pet shops. Of course, there was a difference among facilities, and a significant difference of $P$. hominis infection was observed between pet shops.

Regarding the fecal condition, there was no evidence that $P$. hominis and $T$. foetus infections always induced digestive tract irritation, because no significant differences were demonstrated here between normal feces and soft or diarrhea ones. In agreement with the present results, $P$. hominis infection was commonly presumed to be asymptomatic in dogs and cats (Maritz et al., 2014). However, it has been recently suggested that this organism has the potential for diarrhea in dogs, cats, and humans (Bastos et al., 2018; Kim et al., 2010; Meloni et al., 2011; Zhang et al., 2019). Especially, in humans under the suppressive immune system (e.g., children and adult patients with cancer), P. hominis has been implicated as a causative agent of diarrhea (Meloni et al., 2011; Zhang et al., 2019). In dogs and cats, the coinfection of other protozoa with $P$. hominis is also presumed to increase the incidence of 
diarrhea (Grellet et al., 2013; Michalczyk et al., 2015). As to protozoan T. foetus, the pathogenicity has not been demonstrated in dogs (Li et al., 2016a). In contrast, it is well known that $T$. foetus is a complete pathogen and can cause persistent large-bowel diarrhea in cats (Bastos et al., 2019; Hora et al., 2017; Yao \& Köster, 2015). However, the present study suggests that $T$. foetus is not always associated with the symptomatic infection in cats. Some previous studies have also reported asymptomatic feline cases of $T$. foetus infection (Li et al., 2019; Tysnes, et al., 2011). Similar to in dogs, other factors, such as coinfection, presumably induce the diarrhea in cats (Bastos et al., 2019; Yao \& Köster, 2015).

In conclusion, the results of the present study suggest that the trichomonads parasitized in the intestinal tract are mainly $P$. hominis and $T$. foetus in pet shop puppies and kittens in Japan, respectively, with the low-level invasion. $P$. hominis is determined not only from puppies but also from kittens with a few cases. In contrast, the isolation of $T$. foetus is limited from kittens. The infections of $P$. hominis and $T$. foetus are not always associated with the clinical signs (soft or diarrhea feces). However, as the present results are obtained from limited regions and only a few pet shops, further investigations are necessary for credible evaluation.

\section{References}

Bastos BF, Almeida FM, Brener B. What is known about Tritrichomonas foetus infection in cats? Rev Bras Parasitol Vet 2019; 28(1): 1-11. http://dx.doi.org/10.1590/s1984-29612019005. PMid:30892464.

Bastos BF, Brener B, de Figueiredo MA, Leles D, Mendes-de-Almeida F. Pentatrichomonas hominis infection in two domestic cats with chronic diarrhea.JFMS Open Rep 2018; 4(1): 2055116918774959. http://dx.doi.org/10.1177/2055116918774959. PMid:29872537.

Dąbrowska J, Karamon J, Kochanowski M, Sroka J, Skrzypek K, Zdybel J, et al. Tritrichomonas foetus: A study of prevalence in animal hosts in Poland. Pathogens 2020; 9(3): 203. http://dx.doi.org/10.3390/pathogens9030203. PMid:32164185.

Gookin JL, Stauffer SH, Levy MG. Identification of Pentatrichomonas hominis in feline fecal samples by polymerase chain reaction assay. Vet Parasitol 2007; 145(1-2): 11-15. http://dx.doi.org/10.1016/j.vetpar.2006.10.020. PMid:17127004.

Grellet A, Polack B, Feugier A, Boucraut-Baralon C, Grandjean D, Vandewynckel L, et al. Prevalence, risk factors of infection and molecular characterization of trichomonads in puppies from French breeding kennels. Vet Parasitol 2013; 197(3-4): 418-426. http://dx.doi.org/10.1016/j.vetpar.2013.07.030. PMid:23993636.

Hora AS, Miyashiro SI, Cassiano FC, Brandão PE, Reche-Junior A, Pena HFJ. Report of the first clinical case of intestinal trichomoniasis caused by Tritrichomonas foetus in a cat with chronic diarrhoea in Brazil. BMC Vet Res 2017; 13(1): 109. http://dx.doi.org/10.1186/ s12917-017-1026-3. PMid:28412947.

Kamaruddin M, Tokoro M, Rahman MM, Arayama S, Hidayati APN, Syafruddin D, et al. Molecular characterization of various trichomonad species isolated from humans and related mammals in Indonesia. Korean J Parasitol 2014; 52(5): 471-478. http:// dx.doi.org/10.3347/kjp.2014.52.5.471. PMid:25352694.

Kim YA, Kim HY, Cho SH, Cheun H, Yu JR, Lee SE. PCR detection and molecular characterization of Pentatrichomonas hominis from feces of dogs with diarrhea in the Republic of Korea. KoreanJ Parasito/ 2010; 48(1): 9-13. http://dx.doi.org/10.3347/kjp.2010.48.1.9. PMid:20333280.

Li W, Liu X, Gu Y, Liu J, Luo J. Prevalence of Cryptosporidium, Giardia, Blastocystis, and trichomonads in domestic cats in East China. J Vet Med Sci 2019; 81(6): 890-896. http://dx.doi.org/10.1292/jvms.19-0111. PMid:31105139.

Li WC, Wang K, Zhang W, Wu J, Gu YF, Zhang XC. Prevalence and molecular characterization of intestinal trichomonads in pet dogs in East China. Korean J Parasitol 2016a; 54(6): 703-710. http://dx.doi.org/10.3347/kjp.2016.54.6.703. PMid:28095654.

Li WC, Ying M, Gong PT, Li JH, Yang J, Li H, et al. Pentatrichomonas hominis: prevalence and molecular characterization in humans, dogs, and monkeys in Northern China. Parasitol Res 2016b; 115(2): 569-574. http://dx.doi.org/10.1007/s00436-015-4773-8. PMid:26481488.

Maritz JM, Land KM, Carlton JM, Hirt RP. What is the importance of zoonotic trichomonads for human health? Trends Parasitol 2014; 30(7): 333-341. http://dx.doi.org/10.1016/j.pt.2014.05.005. PMid:24951156.

Meloni D, Mantini C, Goustille J, Desoubeaux G, Maakaroun-Vermesse Z, Chandenier J, et al. Molecular identification of Pentatrichomonas hominis in two patients with gastrointestinal symptoms. J Clin Pathol 2011; 64(10): 933-935. http://dx.doi. org/10.1136/jcp.2011.089326. PMid:21551465.

Michalczyk M, Sokół R, Socha P. Detection of Pentatrichomonas hominis in dogs using real-time PCR. Pol J Vet Sci 2015; 18(4): 775778. http://dx.doi.org/10.1515/pjvs-2015-0100. PMid:26812819.

Molecular Evolutionary Genetics Analysis - MEGA. MEGA 7.0.26 [online]. 2020 [cited 2020 June 17]. Available from: www. megasoftware.net 
National Center for Biotechnology Information - NCBI. BLAST: Basic Local Alignment Search Tool [online]. Bethesda: NCBI; 2020 [cited 2020 June 17]. Available from: http://www.ncbi.nlm.nih.gov/

Tysnes K, Gjerde B, Nødtvedt A, Skancke E. A cross-sectional study of Tritrichomonas foetus infection among healthy cats at shows in Norway. Acta Vet Scand 2011; 53(1): 39. http://dx.doi.org/10.1186/1751-0147-53-39. PMid:21689400.

Yao C, Köster L. Tritrichomonas foetus infection, a cause of chronic diarrhea in the domestic cat. Vet Res 2015; 46(1): 35. http:// dx.doi.org/10.1186/s13567-015-0169-0. PMid:25880025.

Zhang N, Zhang H, Yu Y, Gong P, Li J, Li Z, et al. High prevalence of Pentatrichomonas hominis infection in gastrointestinal cancer patients. Parasit Vectors 2019; 12(1): 423. http://dx.doi.org/10.1186/s13071-019-3684-4. PMid:31462294. 